\title{
PROSPEK PENGELOLAAN WAKAF UANG
}

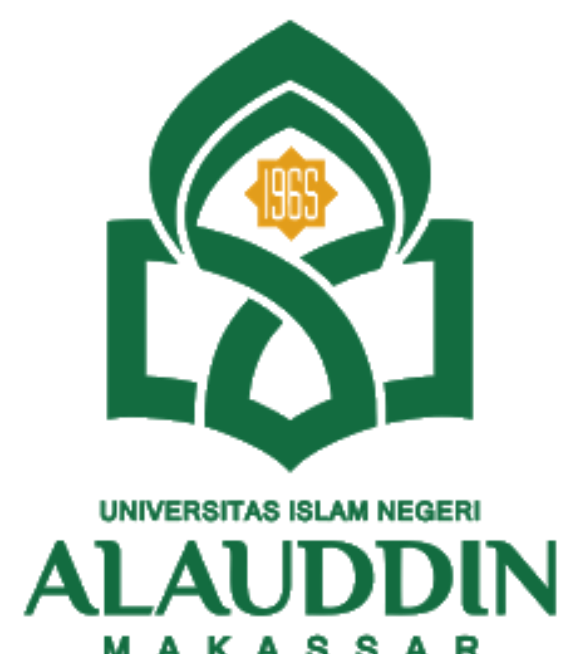

M A K A S S A R

"Didiskusikan pada Mata Kuliah Manajemen ZISWAF Program Studi Perbankan Syariah Semester V Tahun 2021

\section{Disusun Oleh :}

Novira Putri Arlianti (90500119072)

Ainani Adelina (90500119093)

\section{Dosen :}

Supriadi, S.E.I.,M.E.I

\author{
PERBANKAN SYARIAH \\ FAKULTAS EKONOMI DAN BISNIS ISLAM \\ UIN ALAUDDIN MAKASSAR
}

2021/2022 


\section{KATA PENGANTAR}

Puji syukur kami panjatkan kehadirat Allah SWT. Karena telah memberikan segala rahmat, taufik, dan bimbingannya sehingga kami dapat menyelesaikan makalah yang berjudul "Prospek Pengelolaan Wakaf Tunai".

Sholawat dan salam semoga tercurah kepada junjungan kita Nabi Muhammad SAW. Siapa yang membawa kita dari zaman kegelapan ke pertarungan usia terang.

Melalui artikel ini, kami berharap para pembaca dapat mengetahui lebih jauh tentang prospek pengelolaan wakaf uang. Kami selaku penyusun menyadari bahwa masih banyak kesalahan dan kekurangan dalam penulisan artikel ini. Oleh karena itu, kami mengharapkan dan menerima saran dan kritik pembaca dalam berbagai bentuk, saran dan kritik ini sangat membantu untuk perbaikan dan pengembangan makalah selanjutnya.

Makassar, September 2021

Penyusun 


\section{DAFTAR ISI}

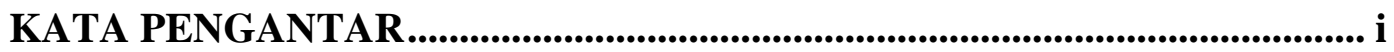

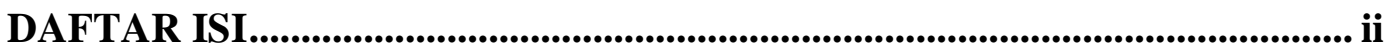

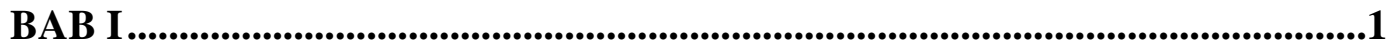

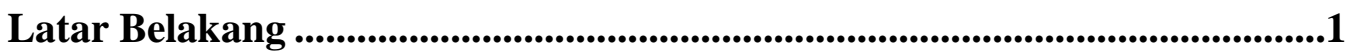

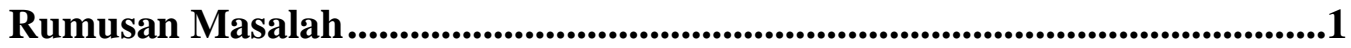

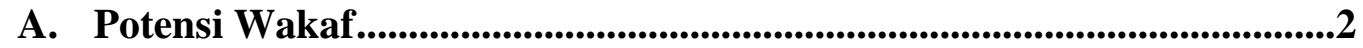

B. Booming Ekonomi Syariah ....................................................................................4

C. Strategi Optimalisasi Pengelolaan Wakaf Uang ...........................................4

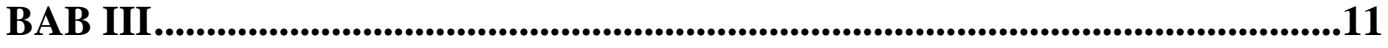

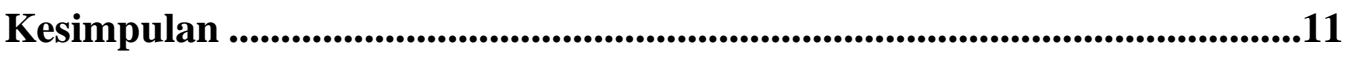

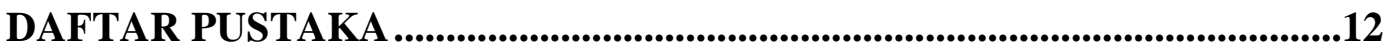




\section{BAB I \\ PENDAHULUAN}

\section{Latar Belakang}

Wakaf tunai sebagai alat keuangan, sebagai salah satu alternatif pemecahan masalah kemiskinan di Indonesia, sebenarnya memiliki prospek yang baik. Beban sosial ekonomi yang dihadapi negara-negara saat ini, seperti tingkat kemiskinan yang tinggi, dapat diselesaikan secara mendasar dan komprehensif dengan mengelola dana kas keagamaan untuk kepentingan ekonomi, sosial, pendidikan, kesehatan, dan keagamaan dalam skala yang lebih luas. Sertifikat wakaf tunai adalah model yang paling efektif dan langgeng untuk mengakumulasi modal sosial dan kekayaan nasional. Selain itu, sertifikat wakaf tunai juga merupakan investasi sosial yang strategis. Padahal, peluang pengembangan wakaf tunai di Indonesia sangat menjanjikan. Karena sejak ekonomi Islam di Nusantara tumbuh subur, semua pihak mulai mengalihkan perhatian dan pemikirannya untuk memenuhi janji dan harapan pengelolaan wakaf tunai.

\section{Rumusan Masalah}

1. Bagaimana Potensi Wakaf Uang ?

2. Bagaimana Booming Ekonomi Syariah ?

3. Bagaimana Strategi Pengoptimalan Pengelolaan Wakaf Uang? 


\section{BAB II}

\section{PEMBAHASAN}

\section{A. Potensi Wakaf Uang}

Di Indonesia, potensi wakaf memang sangat besar. Menurut data yang diterima Presiden, potensi aset wakaf setiap tahun mencapai 2.000 triliun rupiah, di mana potensi wakaf tunai bisa mencapai 188 triliun rupiah.

Mustafa Edwin Nasution pernah berasumsi bahwa populasi Muslim kelas menengah di Indonesia adalah 10 juta, dan pendapatan bulanan rata-rata antara 500.000 dan 10 juta. Menurut perhitungan numerik, ini adalah potensi yang sangat besar. Misalnya, jika 4 juta orang memiliki pendapatan Rp 500.000 dan mereka menyumbangkan aset $\mathrm{Rp} 60.000$ setiap tahun, maka Rp 240 miliar akan dikumpulkan setiap tahun. Jika 2 juta orang menghasilkan 1-2 juta dan menyumbangkan kekayaan 120.000 rupiah setiap tahun, maka 360 miliar akan dikumpulkan. Jika orang yang berpenghasilan 2 hingga 5 juta adalah 2 juta orang, dan menyumbangkan 600.000 dong aset setiap tahun, Ini akan mengumpulkan dana sebanyak \$1,2 triliun. Jika 1 juta orang memiliki pendapatan 5-10 juta dan menyumbangkan 1,2 juta rupiah kekayaan per orang setiap tahun, maka 1,2 triliun akan terkumpul. Sehingga dana yang terkumpul mencapai 3 triliun. Ini adalah aset yang sangat menjanjikan. (Departemen Agama, 2007: 98) 
Wakaf uang secara jelas diatur dalam UU No. 10. nomor 41 tahun 2004. Pembahasan undang-undang tentang wakaf uang menunjukkan bahwa fikih wakaf Indonesia memadukan semangat fiqh dan kebutuhan zaman. Jika wakaf umum dalam fiqh masih berkaitan dengan benda tidak bergerak, seperti tanah dan bangunan, maka hukum telah memperluas cakupan wakaf menjadi benda bergerak. Undang-undang Wakaf memberikan keleluasaan bagi umat Islam untuk mengikuti program wakaf tunai sehingga tidak perlu lagi menunggu kekayaan seperti tuan tanah. Mereka dapat menyisihkan sebagian uang untuk wakaf.

Wakaf tunai memiliki potensi untuk berkembang di Indonesia. Karena dibandingkan dengan model wakaf tradisional, melalui model wakaf ini cakupan mobilisasi akan lebih merata kepada anggota masyarakat, yaitu berupa harta fisik yang biasanya dilakukan oleh keluarga yang relatif kaya. Salah satu model yang dapat dikembangkan dalam mobilisasi wakaf tunai adalah model endowment fund, yaitu menghimpun dana dari berbagai sumber dengan berbagai cara yang legal dan legal. Kemudian, sejumlah besar dana yang terkumpul diinvestasikan dengan cara yang sangat aman melalui lembaga penjaminan syariah ${ }^{1}$.

${ }^{1}$ Abdurrahman Kasdi, "POTENSI EKONOMI DALAM PENGELOLAAN WAKAF UANG DI INDONESIA", Volume 2, No.1, Juni 2014. Hal. 44-45 


\section{B. Booming Ekonomi Syariah}

Penerapan sistem ekonomi syariah merupakan sistem alternatif yang membebaskan umat manusia dari belenggu ketidakadilan ekonomi. Dalam kondisi seperti itu, masyarakat mulai menyadari pengembangan dana akidah produktif (variabel ekonomi syariah) sebagai alat untuk memobilisasi potensi sumber daya ekonomi. Inovasi wakaf tunai sebagai alat keuangan di sektor sukarela dipandang dapat meningkatkan kapasitas ekonomi masyarakat. Pemberian kuasa wakaf dapat digunakan sebagai strategi untuk meningkatkan kesejahteraan rakyat, dan juga dapat digunakan sebagai upaya untuk membebaskan perekonomian negara dari ketergantungan utang luar negeri.

\section{Strategi Optimalisasi Pengelolaan Wakaf Uang}

Secara ekonomi, wakaf tunai memiliki potensi untuk berkembang di Indonesia. Karena model wakaf ini, cakupan mobilisasi akan lebih merata kepada masyarakat dibandingkan model wakaf tradisional yang hanya bisa dilakukan oleh orang kaya. Pengelolaan dana wakaf tunai sebagai alat investasi menjadi menarik, karena pendapatan investasi berupa keuntungan investasi ini akan dinikmati oleh masyarakat lokal, regional dan internasional. Hal ini dimungkinkan karena 
pengembalian investasi dalam bentuk uang tunai dan dapat ditransfer ke penerima manfaat mana pun di seluruh dunia. ${ }^{2}$

Beberapa strategi penting yang perlu diperhatikan untuk mengoptimalkan wakaf uang guna mendukung pemberdayaan dan kesejahteraan umat. Strategi penting yang perlu diperhatikan dalam optimalisasi wakaf tunai untuk mendukung pemberdayaan ekonomi dan peningkatan kesejahteraan masyarakat dapat dilakukan dengan cara sebagai berikut ${ }^{3}$ :

\section{Optimalisasi Edukasi dan Sosialisasi}

Meskipun wakaf uang sudah mulai banyak dikelola oleh lembaga-lembaga Indonesia, seperti TWI, BMM dan badan amal lainnya, namun pengelolaan wakaf uang belum maksimal, sehingga banyak orang yang belum merasakan manfaatnya hingga saat ini. Namun, upaya telah dilakukan untuk memberdayakan wakaf tunai. Untuk itu, dalam rangka mewujudkan pengelolaan dan pengembangan wakaf tunai Indonesia yang terbaik, perlu terus dilakukan sosialisasi tentang wakaf tunai kepada masyarakat. Oleh karena itu, dengan mengoptimalkan pendidikan dan sosialisasi wakaf tunai kepada seluruh komponen masyarakat, maka akan dapat meningkatkan

\footnotetext{
${ }^{2}$ Ika Rinawati, “Manfaat Wakaf Uang Guna Mengatasi Kemiskinan”, Jurnal Perbankan Syariah, Vol.2, No.1, (Januari 2021), h.110

${ }^{3}$ Dr. Rozalinda, M.Ag, FILANTROPI ISLAM DI INDONESIA: STUDI TENTANG PROSPEK WAKAF 
kesadaran masyarakat tentang wakaf. Dalam rangka mewujudkan sosialisasi wakaf uang dengan baik, masyarakat dapat membentuk lembaga wakaf uang dari lingkungan terkecil, seperti masjid, pesantren, perguruan tinggi, atau lembaga swadaya masyarakat yang ada, hingga platform media massa seperti media sosial.

\section{Tindakan Ril Melalui Proyek Percontohan (Pilot Project)}

Pada prinsipnya, jika ada contoh sukses di depan mereka, orang biasanya mengikuti dan berpartisipasi aktif dalam mempromosikan amal Islam ini. Selain itu dilakukan dengan cara efektifitas hasil yang digunakan ${ }^{4}$. Misalnya, bakti sosial yang diberikan dalam bentuk pelayanan kesehatan, seperti RBC, adalah program pengobatan gratis bagi ibu dan anak tidak mampu, khususnya di bidang persalinan. Sejauh ini, sejak berdirinya RBC pada 11 Oktober 2004, RBC telah menyaksikan kelahiran hampir 7.500 bayi dari keluarga miskin dan mendanai pendidikan dan layanan sosial keagamaan lainnya. Anda juga dapat membuat portofolio pengelolaan wakaf. $^{5}$

\footnotetext{
${ }^{4}$ Dr. Rozalinda, M.Ag, FILANTROPI ISLAM DI INDONESIA: STUDI TENTANG PROSPEK WAKAF UANG DALAM PEMBERDAYAAN EKONOMI UMAT

${ }^{5}$ Tamimah, "Model Pengelolaan Wakaf Uang Di Lembaga Sinergi Foundation Dalam Mencapai SDGs”, Jurnal Manajemen Zakat dan Wakaf, Vol.2, No.1, (2021) h. 82-84
} 


\section{Nazhir Wakaf Profesional}

Tidak hanya mengelola aset wakaf di Indonesia, tetapi juga menjadi penguasa global yang mengelola aset wakaf internasional secara profesional tanpa hambatan geografis ${ }^{6}$. Nazhir perlu dapat memaksimalkan aset wakaf untuk memperoleh manfaat yang lebih produktif, serta melakukan pengelolaan yang profesional dan mandiri. Sebagai nazhir wakaf uang, organisasi perlu melakukan beberapa hal agar dapat menghimpun dana wakaf dalam jumlah besar. Nazhir harus mempromosikan konsep wakaf tunai kepada masyarakat. Sosialisasi telah membentuk kesadaran masyarakat akan manfaat besar wakaf tunai. Langkah selanjutnya adalah fundraising, yang berarti menghimpun dana dari masyarakat. Setelah menghimpun dana wakaf, langkah selanjutnya adalah proses pengelolaan wakaf tunai. Ini harus dilakukan dengan cara terbaik sesuai dengan tujuan Nazhir. Pengelolaan dilakukan dengan berinvestasi pada sektor fisik atau portofolio investasi. Sehingga pada akhirnya nanti, mendapatkan hasil yang maksimal dan bisa di sedekahkan kepada mauquf 'alaih secara merata.

\footnotetext{
${ }^{6}$ Acep Zoni Saeful Mubarok, Jurnal Bimas Islam Vol 13 No. 1 Prospek Nazhir Wakaf Global Berbasis Pesantren di Era Digital.
} 


\section{Pengoptimalan Lembaga Regulator}

Sesuai dengan kebijakan pemajuan dan pengembangan keyakinan agama etnis, pemerintah membentuk Komisi Keyakinan Agama Indonesia (BWI). BWI adalah organisasi independen yang didirikan untuk memajukan dan mengembangkan Yayasan Keagamaan Nasional. Misi dan wewenang badan tersebut adalah mengarahkan Nazhir untuk mengelola dan mengembangkan aset wakaf serta memberhentikan dan menggantikan Nazhir ${ }^{7}$.

\section{Pengembangan Wakaf Uang Menjadi Wakaf Properti}

Perlu dikembangkan strategi pengembangan wakaf uang yang tepat adalah dengan mengembangkan wakaf uang menjadi wakaf real estate, seperti real estate konstruksi, hotel, pertokoan (perumahan dan pertokoan), pasar kecil dan pusat niaga lainnya. Hal yang sama berlaku untuk Kementerian Wakaf Mesir. Jika kita telusuri sejarahnya dari masa Kesultanan Utsmaniyah, wakaf Istanbul berkembang sekitar tahun 1456-1551. Jenis wakaf yang populer saat ini adalah wakaf harta dan wakaf uang. Dari seluruh aset wakaf yang ada, $46 \%$ merupakan wakaf tunai. Pada tahun 1925, 600 aset keagamaan menyumbang sepertiga dari luas lahan produksi Turki. Turki merupakan negara yang berhasil mengembangkan aset keagamaan. 
Demikian pula, Dewan Agama Islam Singapura (MUIS) telah bermitra dengan WARES (Singapore Real Estate Waqf) untuk mengembangkan wakaf tunai dalam bentuk sukuk musyarakah untuk mendanai pengembangan real estat. Melalui pengembangan dana wakaf pengembangan real estate dan Dengan pesatnya perkembangan Singapura, seperti pembangunan Beach Road dan Ban Seren Street pada tahun 2005.602, keuntungan dari investasi ini ditujukan untuk masjid, pendidikan dan keuangan, dan orang miskin. Pengembangan wakaf dalam bentuk real estate tentunya membutuhkan kerjasama dengan lembaga keuangan di perbankan syariah. Atau bekerjasama dengan developer yang bergerak di bisnis ini dengan sistem bagi hasil. Real estate yang ada disewakan kepada kalangan menengah ke atas. Keuntungannya kemudian digunakan untuk mendanai pembangunan rumah sederhana murah bagi masyarakat miskin.

\section{Penerapan Good Corporate Governance}

Bentuk pengembangan wakaf tunai ini akan menjamin tingkat produktivitas aset wakaf, karena usaha yang dijalankan lebih menguntungkan, sehingga kelebihan wakaf dapat digunakan untuk membantu meningkatkan kesejahteraan masyarakat miskin. Penerapan tata kelola perusahaan yang baik merupakan salah satu keunggulan kompetitif yang berkelanjutan dari lembaga pengelola wakaf, sebagai proses, sistem, struktur dan aturan yang memberikan nilai tambah bagi lembaga pengelola wakaf tunai. Integritas Nazhir merupakan isu penting dalam pengelolaan dana wakaf, dan Nazhir harus menghindari bentuk-bentuk usaha yang merusak reputasinya. 


\section{BAB III}

\section{PENUTUP}

\section{Kesimpulan}

Wakaf tunai memiliki potensi untuk berkembang di Indonesia. Karena penggunaan model wakaf ini, dibandingkan dengan model wakaf tradisional, cakupan mobilisasi akan lebih merata kepada anggota masyarakat, yaitu berupa aset fisik yang biasanya dilakukan oleh keluarga yang relatif kaya. Salah satu model yang dapat dikembangkan dalam mobilisasi wakaf tunai adalah model endowment fund, yaitu menghimpun dana dari berbagai sumber dengan berbagai cara yang legal dan legal. Kemudian, sejumlah besar dana yang terkumpul diinvestasikan dengan cara yang sangat aman melalui lembaga penjaminan syariah. 


\section{DAFTAR PUSTAKA}

Supriadi. 2021. "BAZNAS Dan Fungsinya." OSF Preprints. November 10. Doi:10.31219/osf.io/fsnwx.

Triwibowo, Ananto. (2020). "Penerapan Prinsip-prinsip Good Corporate Governance Dalam Pengelolaan Wakaf Tunai Pada Badan Wakaf Uang Tunai MUI Yogyakarta”. Vol 4. No.1. h.123-146

Rozalinda, FILANTROPI ISLAM DI INDONESIA: STUDI TENTANG PROSPEK WAKAF UANG DALAM PEMBERDAYAAN EKONOMI UMAT

Mubarok, Saeful, Zoni, Acep. "Prospek Nazhir Wakaf Global Berbasis Pesantren di Era Digital”. Jurnal Bimas Islam Vol 13 No. 1

Kasdi, Abdurrahman. (2014). "POTENSI EKONOMI DALAM PENGELOLAAN WAKAF UANG DI INDONESIA”, Vol.2. No.1. h. 44-45

Rinawati, Ika. (2021). “Manfaat Wakaf Uang Guna Mengatasi Kemiskinan”. Jurnal Perbankan Syariah. Vol.2. No.1.

Tamimah. (2021). "Model Pengelolaan Wakaf Uang Di Lembaga Sinergi Foundation Dalam Mencapai SDGs”, Jurnal Manajemen Zakat dan Wakaf. Vol.2. No.1. h. $82-84$ 